\title{
Solar Power Plant Planning with Tile Modification for Solar Panel Installation
}

\author{
Sagita Rochman \\ Department of Electrical Engineering \\ University of PGRI Adi Buana Surabaya \\ sagita@unipasby.ac.id
}

\author{
Achmad Alfianto \\ Department of Electrical Engineering \\ University of PGRI Adi Buana Surabaya \\ achmadalfianto02@gmail.com
}

Solar power plants have been created using solar cells as power plants. This power plant utilizes the source of sunlight as its source. Solar cell as receiving sunlight as a source of electricity. Utilization of sunlight to become electrical energy, Designed from tile as a medium and solar cell as a receiver of solar energy into electrical energy. Where battery as a charging to be used, this tile as a tool planted solar cell so that it can be used tools that generate electrical energy. Solar power is one of the environmentally friendly renewable energy sources. Solar power is utilized by solar power plants to generate electricity. The electrical energy generated is the light energy converted by solar cells. The solar cell pool is arranged in such a way that it produces solar panels. The resulting electrical energy will be stored in a medium called.

Keywords-Battery, Tile, Sun, Solar cell, Solar Charge Controller.

\section{INTRODUCTION}

The need for the plant to cover PLN as an efficient power source, one of the generators commonly used is a diesel generator because the fast starting process does not require a wide space to put it. But in this study does not suggest using diesel generators but rather using Photovoltaic or better known as solar panels as backup energy because the use of diesel generators is not environmentally friendly and also the additional operational costs in the purchase of fuel is quite large compared to renewable energy-based plants. In this study proposed the use of solar power system plants as a generator at home. Solar power generation is the right solution, especially to answer the problem of costs that must be spent to pay for electricity costs. It can be said that solar power systems are more efficient, efficient, and economical. In this study explains about how.

\section{METHODS}

\subsection{Electronic Design System Design Scheme}

In this scheme is designed placement of solar cell tile on the house along with the roof of the house or tile while the control is in the house, For electronic design scheme or components.

Photovoltaic system is a power source derived from solar power generation system, photovoltaic system can only generate power out when the photovoltaic module is illuminated by the sun, then the photovoltaic system transfers radiation using an energy storage mechanism so that electricity energy remains available and can be used when the sun is at the end of the evening and when the sun is no longer illuminating the earth (night). Batteries are equipment used to store electrical energy obtained from photovoltaic arrays. One of the electrical energy storage tools is the battery, in addition it can also be used to regulate the voltage system of the current source, before setting up an alternative system that utilizes Solar Cell.

\subsection{Product Results and Evaluation}

Before explaining the voltage settings of each component, please be aware of the specifications used in plts so that the work of each component is more optimal. To determine the specifications of the components, we first design or estimate what loads will be used.

\subsection{Data Testing and Presentation}

Determine the specifications of solar panels By designing the load to be used, we can determine the specifications of solar panels used, then we can proceed to the next stage. And the stages are described as follows: 


\subsection{Series of Solar Modules in Parallel}

To obtain an electric current greater than the output of the electric current of each solar module, the solar module is connected in parallel, by connecting the same poles (negative poles are connected and positive poles are also connected).

When each solar module has a working voltage of $12 \mathrm{Volt}$ and generates an electric current of $1.5 \mathrm{watt}$ each, then one tile is connected to a series so that it gets a voltage of $24 \mathrm{v}$.

\subsection{Series of Solar Modules}

To obtain the desired voltage solar module is connected in series that is by connecting positive poles and negative poles. The total voltage obtained by connecting the series of four tile modules each has a voltage of 12 Volts is the amount of 25 Volts.

\subsection{Voltage Settings On Solar Panels}

Voltage regulation by solar panels relates to the amount of voltage produced.

\subsection{Data Analysis}

Based on the data obtained in this study, data analysis is carried out gradually and carefully and thoroughly. With the analysis of the data obtained this produces the following:
a. Voltage production of solar cells
b. The resulting current
c. Measurement of light.
d. Testing

Table 1. charging analysis first day

\begin{tabular}{|r|r|c|r|c|}
\hline \multicolumn{1}{|c|}{ hour } & \multicolumn{1}{c|}{ light } & current & \multicolumn{1}{c|}{ volt } & watt \\
\hline $7: 00$ & 600 & 0,26 & 13 & 3,38 \\
\hline $8: 00$ & 2000 & 0,28 & 13 & 3,64 \\
\hline $9: 00$ & 3200 & 0,28 & 13 & 3,64 \\
\hline $10: 00$ & 3200 & 0,28 & 13 & 3,64 \\
\hline $12: 00$ & 3300 & 0,28 & 13 & 3,64 \\
\hline $13: 00$ & 3300 & 0,28 & 13 & 3,64 \\
\hline $14: 00$ & 3100 & 0,28 & 13 & 3,64 \\
\hline $15: 00$ & 2500 & 0,28 & 13 & 3,64 \\
\hline $16: 00$ & 2000 & 0,28 & 13 & 3,64 \\
\hline
\end{tabular}

Figure. 1 Graphic of Power Output first day 
BEST

Journal of Applied Electrical \& Science Technology - University of PGRI Adi Buana Surabaya

Table 2. charging analysis second day

\begin{tabular}{|c|c|c|c|c|}
\hline hour & light & current & volt & watt \\
\hline $7: 00$ & 1500 & 0,26 & 13 & 3,38 \\
\hline $8: 00$ & 2000 & 0,28 & 13 & 3,64 \\
\hline $9: 00$ & 3200 & 0,28 & 13 & 3,64 \\
\hline $10: 00$ & 3200 & 0,28 & 13 & 3,64 \\
\hline $12: 00$ & 3300 & 0,28 & 13 & 3,64 \\
\hline $13: 00$ & 3300 & 0,28 & 13 & 3,64 \\
\hline $14: 00$ & 3100 & 0,28 & 13 & 3,64 \\
\hline $15: 00$ & 2500 & 0,28 & 13 & 3,64 \\
\hline $16: 00$ & 2000 & 0,28 & 13 & 3,64 \\
\hline
\end{tabular}

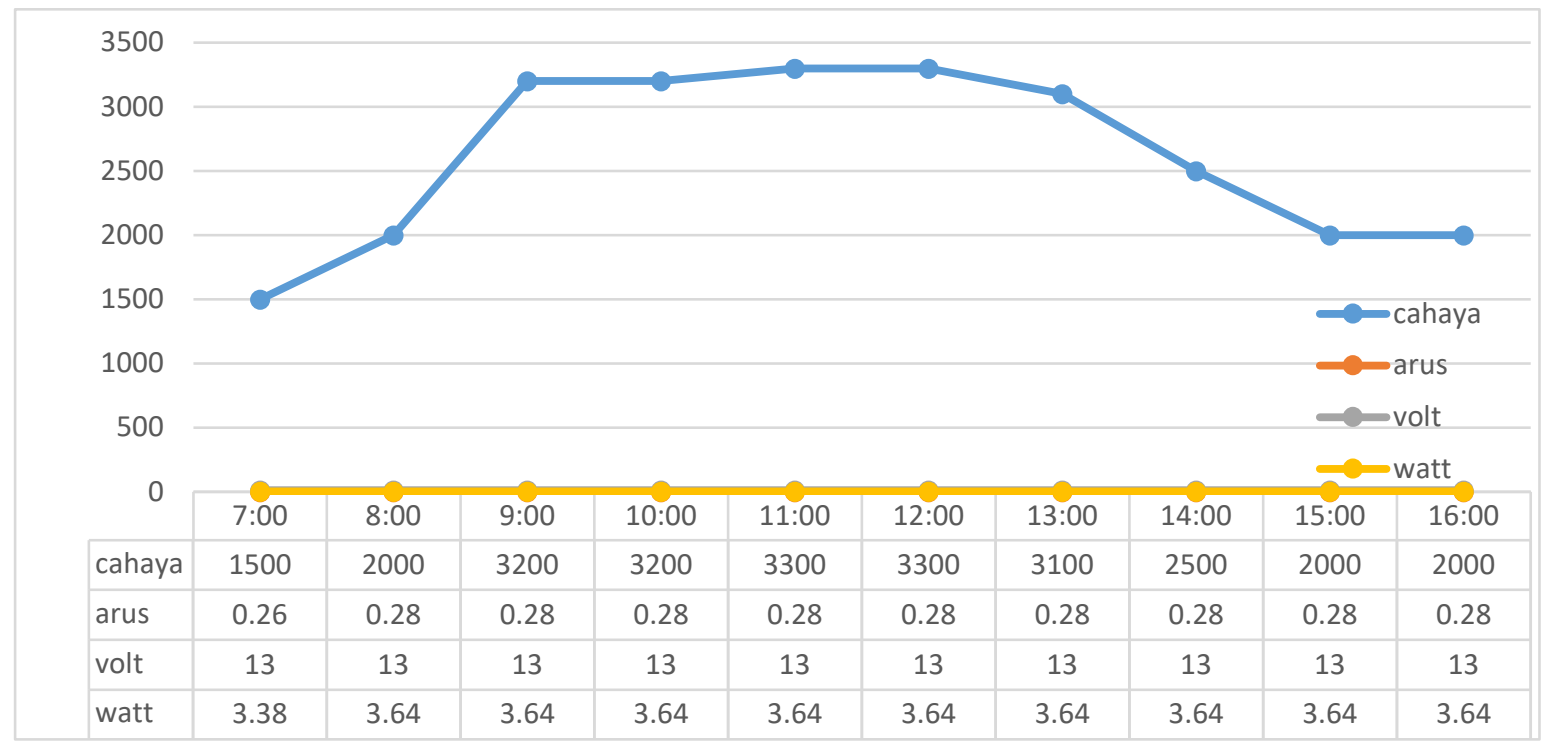

Figure. 2 Graphic of Power Output second day

\subsection{Discussion}

In the design of solar power plants with tile modifications for home lighting with the purpose of easy to use and efficient, the house looks more beautiful than using solar cells in general and easy to install without having to be confused, and works well so that the bias is used when the lights are off as an electricity backup or make electricity that is far from the range of electricity.

\subsection{Product design}

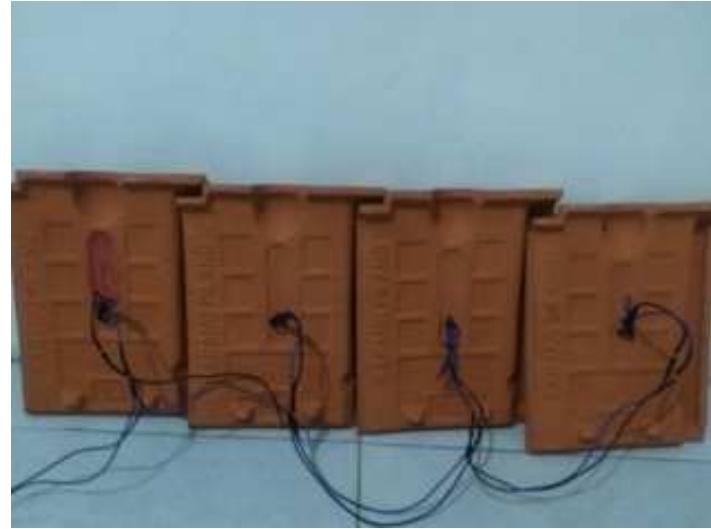

Figure. 3 Product Design 


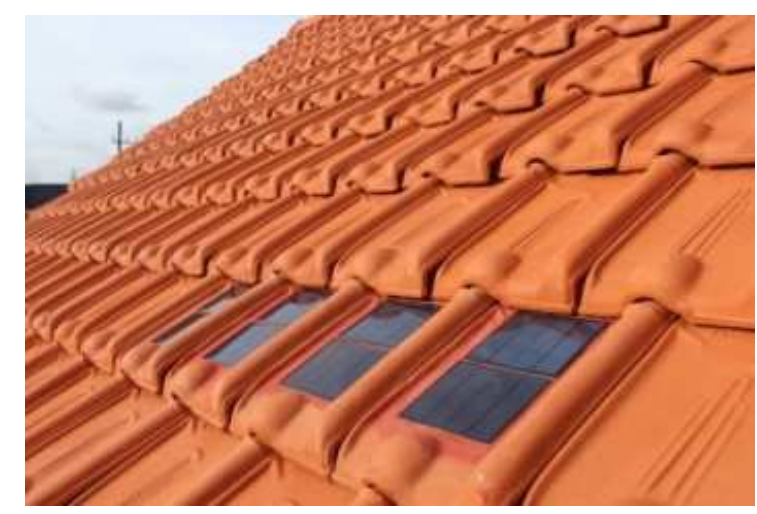

Figure. 4 Product Design

\section{CONCLUSION}

From a series of research, testing and analysis of solar cells with tile as a planting medium can be concluded as follows:

1. Voltage regulation is very important in a generating system, because if the voltage is unstable it can damage the electrical equipment.

2. Voltage regulation by the battery charge controller is intended so that there is no overcharging, over discharge and over loading that can lead to reduced battery life time.

3. Voltage is strongly influenced by the intensity of light absorbed by solar panels, the higher the intensity of light absorbed the greater also the voltage produced, in contrast to the temperature of the solar panel that also affects the resulting voltage, the higher the temperature of the panel, the less voltage will be.

4. Batteries are one of the brains of solar power plants, therefore the determination of battery voltage specifications needs to be considered, which is also the voltage of the battery system.

5. Voltage setting by the inverter is to change the voltage of $12 \mathrm{~V} \mathrm{DC}$ to $220 \mathrm{~V} \mathrm{AC}$, so that the user can use the ac load.

\section{REFERENCES}

[1] Azmal Harun Arrasyid, Didik Notosoedjono, Hasto Subagya. 2016.Perencanaan Penerangan Jalan
Umum Dan Lampu Taman Berbasis Photovoltaik di Universitas Pakuan Bogor. Program Studi Teknik Elektro,Fakultas Teknik Universitas Pakuan.

[2] Kadir, Abdul, Energie : Sumber Daya, Inovasi, Tenaga Listrik dan Potensi Ekonomi(Jakarta : UI Press, 1990)

[3] K. Kananda and R. Nazir, "Konsep Pengaturan Aliran Daya Untuk PLTS Tersambung Ke Sistem Grid Pada Rumah Tinggal," J. Nas. Tek. Elektro, vol. 2, no. 2, pp. 65-71,2013.

[4] MUHAMMAD HIDAYAT.2020 Kampus Universitas Muhammadiyah Makassar, Perancangan Penerangan Jalan Umum Tenaga Surya (Solar Cell) Untuk Alternative Penerangan

[5] R. Wiryadinata, A. I. S, R. Munarto, J. T. Elektro, U. Sultan, and A. Tirtayasa, "Studi Pemanfaatan Energi Matahari di Pulau Panjang Sebagai Pembangkit Listrik Alternatif," vol. 2, no. 1,2013.

[6] Rochman, Sagita. "DESIGN OF VERTICAL AXIS SAVONIUS WINDMILL FOR GENERATING ELECTRICITY USING PERMANENT MAGNET." Tibuana 3.01 (2020): 61-66.

[7] Sujiwa, Akbar, and Sagita Rochman. "Pengembangan Sistem Kontrol Serta Monitoring Suhu dan Volume Air Berbasis Web Pada Perangkat Desalinasi Air Laut." SNHRP (2019): 1-9.

[8] Mukhtar, M. Nushron Ali, and Sagita Rochman. "ANALISIS SIMULASI PROSES IRONING UNTUK MENGETAHUI KETINGGIAN DINDING BERDASARKAN VARIASI REDUKSI KETEBALAN DINDING." WAKTU: Jurnal Teknik UNIPA 15.2 (2017): 66-72.

[9] Rochman, Sagita, and M. Nushron Ali Mukhtar. "CLASSIFICATION OF THE QUALITY OF HONEY USING THE SPECTROFOTOMETER AND MACHINE LEARNING SYSTEM BASED ON SINGLE BOARD COMPUTER." Tibuana 2.01 (2019): 45-49.

[10] Rochman, Sagita. "DESIGN OF VERTICAL AXIS SAVONIUS WINDMILL FOR GENERATING ELECTRICITY USING PERMANENT MAGNET." Tibuana:: Journal of Applied Industrial Engineering 3.01 (2020): 61-66. 
Journal of Applied Electrical \& Science Technology - University of PGRI Adi Buana Surabaya

[11] Rochman, Sagita, and Akbar Sujiwa. "PENINGKATAN DAYA OUTPUT GENERATOR LISTRIK TIPE AFPMG PADA PUTARAN RENDAH MENGGUNAKAN 3 ROTOR DAN 2 STATOR."

[12] Suryawati, Indri, and Sagita Rochman. "GENERATOR FUEL COST OPTIMIZATION USING ANT COLONY ALGORITHM." BEST: Journal of Applied Electrical, Science, \& Technology 1.1 (2019): 1-4. 